Journal of Health Promotion and Behavior (2019), 4(2): 126-136

https://doi.org/10.26911/thejhpb.2019.04.02.05

\title{
Application of Theory of Planned Behavior on Sexual Behavior in Female Adolescents
}

\author{
Tri Ayu Setiowati'), Eti Poncorini Pamungkasari²), Hanung Prasetya ${ }^{3)}$ \\ ${ }^{1)}$ Masters Program in Public Health, Universitas Sebelas Maret \\ 2)Faculty of Medicine, Universitas Sebelas Maret \\ 3)School of Health Polytechnics Surakarta
}

\begin{abstract}
Background: In Indonesia, someone starts having a relationship for the first time in their teens. A woman starts having a relationship at the age of 15-17 years (33.3\%). In addition, a man starts having a relationship at the age of 15 years (34.5\%). Sex behavior in adolescents had high consequences in physical and psychosocial health problems. The purpose of this study was to determine sexual behavior in female adolescents using Theory of Planned Behavior.

Subjects and Method: This was a cross-sectional study conducted in Bantul, Yogyakarta, from June to July 2019. A sample of 200 female adolescents was selected by sample using random sampling. The dependent variable was sexual behavior. The independent variables were intention, attitude, subjective norm, perceived behavioral control, behavioral belief, normative belief, and control belief. The data were collected by questionnaire and analyzed by path analysis.

Results: Positive sexual behavior in female adolescents was directly and positively affected by intention $(b=3.22 ; 95 \% \mathrm{CI}=1.46$ to $4.97 ; \mathrm{p}<0.001)$ and perceived behavioral control $(\mathrm{b}=2.42 ; 95 \%$ $\mathrm{CI}=1.23$ to $3.61 ; \mathrm{p}<0.001)$. Positive sexual behavior was indirectly affected by attitude, subjective norm, perceived behavioral control, behavioral belief, normative belief, and control belief.

Conclusion: Positive sexual behavior in female adolescents is directly and positively affected by intention and perceived behavioral control. It is indirectly affected by attitude, subjective norm, perceived behavioral control, behavioral belief, normative belief, and control belief.
\end{abstract}

Keywords: sexual behavior, adolescents, Theory of Planned Behavior, path analysis

\section{Correspondence:}

Tri Ayu Setiowati. Masters Program in Public Health, Universitas Sebelas Maret. Jl. Ir. Sutami 36A, Surakarta 57126, Central Java. Email: triayu.setiowati@gmail.com. Mobile: 085329680266.

\section{BACKGROUND}

According to the World Health Organization (WHO), adolescents are residents in the age range of 10-19 years. According to the Regulation of Ministry of Health RI Number 25 of 2014, adolescents are residents in the age range of 10-18 years. According to the National Population and Family Planning Board(BKKBN), the age range of adolescents is 10-24 years and not married yet. According to the 2010 Population Cencus, the total age group of 10-19 years in Indonesia was 43.5 million or around $18 \%$ of the population. It was estimated that adolescent groups were 1.2 billion or $18 \%$ of the world's population (Ministry of Health RI, 2015).

Adolescence is a period of rapid growth and development both physically, psychologically, and intellectually. Adolescents have great curiosity, love challenges and adventures, and tend to be brave in taking the risks of their actions without any careful consideration. If they make a wrong decision when facing a conflict, they will fall into risky behavior. Besides, they may have to take the short and long term consequences of various physical and psychosocial health problems (Ministry of Health RI, 2015). 
Sexual behavior is all actions due to the sexual desire towards the opposite and the same sex (Sarwono, 2011). The premarital sexual behavior in adolescents are feeling attracted to the opposite sex, dating, holding hand, hugging, kissing cheek and lip, and having sex. The sexual objects in adolescents who have sexual behavior are other people, people who are in their imagination, and themselves (Azinar, 2013).

In Indonesia, someone starts having a relationship for the first time in their teens. A woman starts having a relationship at the age of 15-17 years (33.3\%). In addition, a man starts having a relationship at the age of 15 years (34.5\%) (Ministry of Health RI, 2015).

The result of a survey of adolescent reproductive health in the Special Region of Yogyakarta in 2011 showed that $77.98 \%$ of adolescents had had dating experiences. The sexual behavior during dating was holding hands or hugging by $88.70 \%$, kissing lips by $49.17 \%$, touching the genitals of their mate by $13.29 \%$, and having sex by 12.29\% (National Population and Family Planning Board, 2011).

The causes of premarital sexual behavior in adolescents are: 1) personal factors: knowledge, attitude towards health services, lifestyle, self-control, social activities, self-confidence and demographic variables such as age and religion; 2) characteristics of environment, such as access and contact with the information sources, social and culture, values and norms as social support for certain behaviors, 3) characteristics of family: parental status and education; 4) characteristics of peers, such as peer sexual behavior (Suryoputro et al., 2006).

Theory of Planned Behavior is a theory that predicts the consideration of behavior because it can be considered and planned (Ajzen, 2005).
This study aims to analyze the factors that affect sexual behavior among female adolescents based on the Theory of Planned Behavior (TPB).

\section{SUBJECTS AND METHOD \\ a. Study Design}

This was an analytic observational study with a cross-sectional design. This study was conducted in five senior high schools in Bantul, Yogyakarta, from June to July 2019.

\section{b. Population and Sample}

The target population of this study was all XI grade State Senior High School female students in Bantul Regency, Yogyakarta. This study used simple random sampling to get the 200 female students.

\section{c. Study Variables}

The dependent variable was sexual behavior. The independent variables were intention, attitude, subjective norm, perceived behavioral control, behavioral belief, normative belief, and control belief.

\section{d. Operational Definition of Variables} Sexual behavior of female adolescent was a sexual behavior carried out by female adolescent such as kissing, holding hands, touching/holding genitals of the opposite sex, and having sex.

The intention of adolescent was the tendency of a female adolescent to do or not to do sexual behavior.

Attitude was an expression of feelings or beliefs and a form of overall evaluation of a female adolescent when dealing with statements about sexual behavior in adolescents.

Subjective norm was a perception or point of view of a female adolescent towards expectations of others (parents, friends, teachers) that could affect the adolescent decision to do or not to do the sexual behavior. 
Journal of Health Promotion and Behavior (2019), 4(2): 126-136

https://doi.org/10.26911/thejhpb.2019.04.02.05

Perceived behavioral control was a perception of a female adolescent regarding the ability to control herself in doing or not doing the sexual behavior.

Behavioral belief was a belief or point of view of a female adolescent regarding the good or bad sexual behavior.

Normative belief was a belief or point of view of a person (friend, family, or teacher) regarding the good or bad sexual behavior in adolescents.

Control belief was a belief or point of view of a female adolescent regarding the factors that could support or inhibit the sexual behavior.

\section{e. Instrument of the Study}

This study used primary and secondary data. Primary data were obtained using questionnaires filled out by the study subjects. Secondary data were obtained from the Education Office, Bantul Regency, in the form of data from school and data from Senior High School female students in Bantul Regency. This study used questionnaires.

\section{f. Data Analysis}

Univariate analysis aimed to explain and describe the characteristics of each independent and dependent variable based on primary and secondary data. Bivariate analysis was conducted to determine the correlation between sexual behavior and the factors that affected it using the chi-square test. Multivariate data analysis in this study used path analysis to determine the direct or indirect effects of the independent variables: factors that affected the sexual behavior among female adolescents.

\section{g. Research Ethics}

Research ethics consisted of informed consent form, anonymity, confidentiality, and ethical clearance. Ethical clearance in this study came from the Health Research Ethics Committee of Dr. Moewardi Hos- pital, Surakarta, Central Java, with No. 890/VII/HREC/2019.

RESULTS
1. Sample Characteristics
Table 1 showed that there were 187 female
adolescents with strong intention (93.5\%). There were 174 female adolescents with positive attitude (87\%). There were 168 female adolescents with positive subjective norm (84\%). In terms of perceived control, there were 179 female adolescents who had strong perceived control (89.5\%). There were 161 female adolescents who had positive behavior belief (83\%). There were 171 female adolescents who had positive normative belief (85.5\%). There were 164 female adolescents with strong control belief ( $83 \%)$.

\section{Bivariate Analysis}

Table 2 shows the result of the bivariate analysis of the independent and dependent variables. Table 2 shows that intention $(\mathrm{OR}=58.78 ; \mathrm{p}<0.001)$, attitude $(\mathrm{OR}=9.08$; $\mathrm{p}<0.001)$, subjective norm $(\mathrm{OR}=14.27$; $\mathrm{p}$ $<0.001)$, perceived behavioral control ( $\mathrm{OR}=$ 14.57; $\mathrm{p}<0.001)$, behavioral belief $(\mathrm{OR}=$ 11.66; $\mathrm{p}<0.001)$, normative belief $(\mathrm{OR}=$ 4.76; $\mathrm{p}<0.001)$, and control belief $(\mathrm{OR}=$ 2.70; $p=0.026$ ) increased positive sexual behavior.

\section{Path Analysis}

\section{a. Model Specification}

Model specification was used to describe the variables would be examined. Variables in this study were attitude, subjective norm, perceived behavioral control, intention, behavioral belief, normative belief, control belief, and sexual behavior.

\section{b. Model Identification}

The measurement variables consisted of:

1) Number of measurement variables $=8$

2) Endogenous variables $\quad=5$

3) Exogenous variables $\quad=3$

4) Number of parameters $=8$ 
Degree of freedom (df) was as follows:

$=$ (number of measurement variables $\mathrm{x}$ (number of measurement variables+1)/2) (endogenous variables + exogenous variables + number of parameters)
$=(8 \times(8+1) / 2)-(5+3+8)$

$=(72 / 2)-16=36-16=20$

Path analysis could be conducted if $\mathrm{df}>0$. $\mathrm{Df}=20$ means over identified, so that path analysis could be done.

Table 1. Sample characteristics

\begin{tabular}{lcc}
\hline Characteristics & N & (\%) \\
\hline Intention & 187 & 93.5 \\
Strong & 13 & 6.5 \\
Weak & 174 & 87 \\
Attitude & 26 & 13 \\
Positive & 168 & \\
Negative & 32 & 84 \\
Subjective Norm & & 16 \\
Positive & 179 & 89.5 \\
Negative & 21 & 10.5 \\
Perceived Control & & \\
Strong & 161 & 83 \\
Weak & 39 & 17 \\
Behavioral Belief & & 85.5 \\
Positive & 171 & 14.5 \\
Negative & 29 & 83 \\
Normative Belief & & 17 \\
Positive & 164 & \\
Negative & 36 & \\
Control Belief & & \\
Strong & & \\
Weak & & \\
\hline
\end{tabular}

Table 2. The results of bivariate analysis

\begin{tabular}{|c|c|c|c|c|c|c|c|c|}
\hline \multirow{3}{*}{ Variables } & \multicolumn{4}{|c|}{ Sexual Behavior } & \multirow{2}{*}{\multicolumn{2}{|c|}{ Total }} & \multirow{3}{*}{ OR } & \multirow{3}{*}{$\mathbf{p}$} \\
\hline & \multicolumn{2}{|c|}{ Positive } & \multicolumn{2}{|c|}{ Negative } & & & & \\
\hline & $\mathbf{n}$ & $\%$ & $\mathbf{n}$ & $\%$ & $\mathbf{N}$ & $\%$ & & \\
\hline \multicolumn{9}{|l|}{ Intention } \\
\hline Strong & 171 & 91.4 & 16 & 8.6 & 187 & 100.0 & \multirow{3}{*}{58.78} & \multirow{3}{*}{$<0.001$} \\
\hline Weak & 2 & 15.0 & 11 & 85.0 & 13 & 100.0 & & \\
\hline \multicolumn{7}{|l|}{ Attitude } & & \\
\hline Positive & 159 & 91.5 & 15 & 8.5 & 174 & 100.0 & \multirow{3}{*}{9.08} & \multirow{2}{*}{$<0.001$} \\
\hline Negative & 14 & 55.0 & 12 & 45.0 & 26 & 100.0 & & \\
\hline \multicolumn{8}{|l|}{ Subjective Norm } & \\
\hline Positive & 157 & 93.5 & 11 & 6.5 & 168 & 100.0 & \multirow{3}{*}{14.27} & \multirow{3}{*}{$<0.001$} \\
\hline Negative & 16 & 50.0 & 16 & 50.0 & 32 & 100.0 & & \\
\hline \multicolumn{7}{|l|}{ Perceived Control } & & \\
\hline Strong & 164 & 91.6 & 15 & 8.4 & 179 & 100.0 & \multirow{3}{*}{14.57} & \multirow{2}{*}{$<0.001$} \\
\hline Weak & 9 & 42.9 & 12 & 57.1 & 21 & 100.0 & & \\
\hline \multicolumn{8}{|l|}{ Behavioral Belief } & \\
\hline Positive & 151 & 93.8 & 10 & 6.2 & 161 & 100.0 & \multirow{3}{*}{11.66} & \multirow{3}{*}{$<0.001$} \\
\hline Negative & 22 & 56.4 & 17 & 43.6 & 39 & 100.0 & & \\
\hline \multicolumn{7}{|l|}{ Normative Belief } & & \\
\hline Positive & 154 & 90.0 & 17 & 10.0 & 171 & 100.0 & \multirow{3}{*}{4.76} & \multirow{2}{*}{$<0.001$} \\
\hline Negative & 19 & 65.5 & 10 & 34.5 & 29 & 100.0 & & \\
\hline \multicolumn{8}{|l|}{ Control Belief } & \\
\hline Strong & 146 & 89.0 & 18 & 11.0 & 164 & 100.0 & \multirow{2}{*}{2.70} & \multirow{2}{*}{0.026} \\
\hline Weak & 27 & 75.0 & 9 & 25.0 & 36 & 100.0 & & \\
\hline
\end{tabular}


Journal of Health Promotion and Behavior (2019), 4(2): 126-136

https://doi.org/10.26911/thejhpb.2019.04.02.05

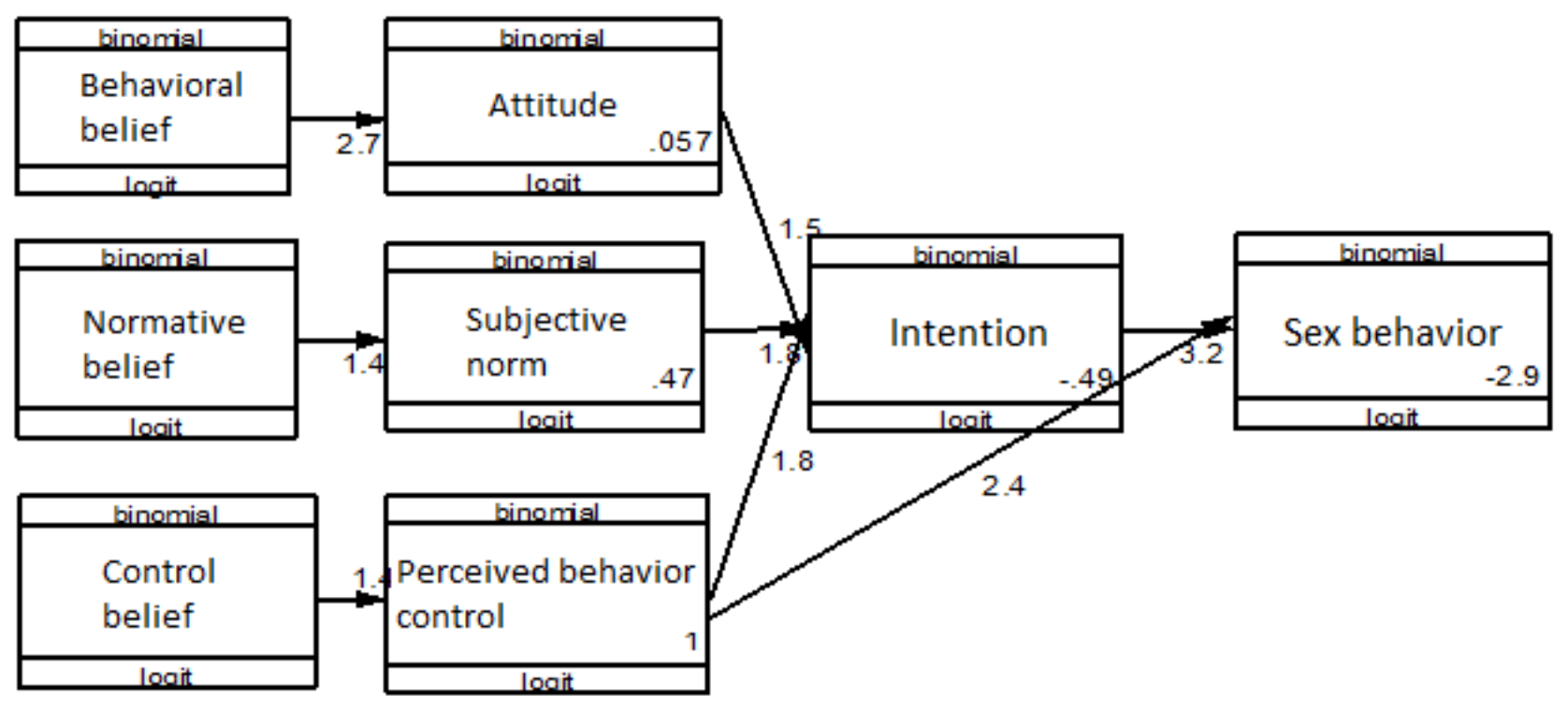

Figure 1. Path Analysis Model with Estimated Value

Table 3 shows the result of path analysis. Sexual behavior among female adolescents was directly and positively affected by intention which was statistically significant. Adolescents with strong intention had logodd to do healthy sexual behavior by 3.22 units greater than weak intention $(b=$ 3.22; $95 \% \mathrm{CI}=1.46$ to 4.97 ; $\mathrm{p}<0.001$ ).

Sexual behavior was directly and positively affected by perceived behavioral control which was statistically significant. Female adolescents with strong perceived behavioral control had logodd to do healthy sexual behavior by 2.42 units greater than weak perceived behavioral control $(\mathrm{b}=$ 2.42; $95 \% \mathrm{CI}=1.23$ to $3.61 ; \mathrm{p}<0.001$ ).

There was a direct and close to significant effect of attitude on intention. Female adolescents with positive attitude were likely to have positive intention by 1.45 units greater than adolescents with negative attitude $(b=1.45 ; 95 \% \mathrm{CI}=-0.04$ to $2.96 ; \mathrm{p}=0.057$ ).

There was a direct and positive effect of subjective norm on intention. Female adolescents with positive subjective norm were likely to have positive intention by 1.77 units greater than adolescents with negative subjective norm $(b=1.77 ; 95 \% \mathrm{CI}=$ 0.21 to $3.33 ; \mathrm{p}=0.026$ ).

There was a direct and positive effect of perceived behavioral control on intention. Female adolescents with strong perceived behavioral control were likely to have positive intention by 1.79 units greater than adolescents with weak perceived behavioral control $(b=1.79 ; 95 \% \mathrm{CI}=0.27$ to $3.31 ; \mathrm{p}=0.021)$.

There was a direct and positive effect between behavioral belief and attitude in adolescents. Female adolescents who had positive behavioral belief were likely to have positive attitude by 2.68 units greater than adolescents who had negative behavior belief $(b=2.68 ; 95 \% \mathrm{CI}=1.76$ to $3.60 ; \mathrm{p}$ $<0.001$ ).

There was a direct and positive effect of normative belief on subjective norm in adolescents. Female adolescents with positive normative belief were likely to have positive subjective norm by 1.36 units greater than adolescents who had negative normative belief $(b=1.36$; $95 \% \mathrm{CI}=0.46$ to 2.26; $\mathrm{p}=0.003$ ).

There was a direct and positive effect of control beliefs on perceived behavioral 
control in adolescents. Female adolescents who had positive control belief were likely to have strong perceived behavioral control by 1.44 units greater than adolescents with negative control belief $(b=1.44 ; 95 \% \mathrm{CI}=$ 0.49 to $2.39 ; \mathrm{p}=0.003$ ).

Table 3. The results of the path analysis

\begin{tabular}{|c|c|c|c|c|c|c|}
\hline \multirow[b]{2}{*}{$\begin{array}{l}\text { Dependent } \\
\text { variable }\end{array}$} & & \multirow[b]{2}{*}{ Independent variable } & \multirow[b]{2}{*}{$\mathbf{b}$} & \multicolumn{2}{|c|}{$95 \% \mathrm{CI}$} & \multirow[b]{2}{*}{$\mathbf{p}$} \\
\hline & & & & $\begin{array}{l}\text { Lower } \\
\text { limit }\end{array}$ & $\begin{array}{l}\text { Upper } \\
\text { limit }\end{array}$ & \\
\hline \multicolumn{7}{|l|}{ Direct effect } \\
\hline \multirow[t]{2}{*}{ Positive sex behavior } & $\leftarrow$ & Intention (positive) & 3.22 & 1.46 & 4.97 & $<0.001$ \\
\hline & $\leftarrow$ & $\begin{array}{l}\text { Perceived behavior control } \\
\text { (strong) }\end{array}$ & 2.42 & 1.23 & 3.61 & $<0.001$ \\
\hline \multicolumn{7}{|l|}{ Indirect effect } \\
\hline \multirow[t]{3}{*}{ Intention (strong) } & $\leftarrow$ & Attitude (positive) & 1.45 & -0.04 & 2.96 & 0.057 \\
\hline & $\leftarrow$ & Subjective norm (positive) & 1.77 & 0.21 & 3.33 & 0.026 \\
\hline & $\leftarrow$ & $\begin{array}{l}\text { Perceived behavior control } \\
\text { (strong) }\end{array}$ & 1.79 & 0.27 & $3 \cdot 31$ & 0.021 \\
\hline Attitude & $\leftarrow$ & Behavior belief (positive) & 2.68 & 1.76 & 3.60 & $<0.001$ \\
\hline Subjective norm & $\leftarrow$ & Normative belief (positive) & 1.36 & 0.46 & 2.24 & 0.003 \\
\hline $\begin{array}{l}\text { Perceived behavior } \\
\text { control (strong) } \\
\text { N observation }=200 \\
\text { Log likelihood }=-296\end{array}$ & $\leftarrow$ & Control belief (strong) & 1.44 & 0.49 & 2.39 & 0.003 \\
\hline
\end{tabular}

\section{DISCUSSION}

1. The Effect of Intention on Sexual

Behavior in Female Adolescents

The result of the study showed that strong intention had a direct and positive effect on sexual behavior in female adolescents $(b=$ 3.22; 95\% $\mathrm{CI}=1.46$ to $4.97 ; \mathrm{p}<0.001)$ and it was statistically significant.

This study is in accordance with the Theory of Planned Behavior (TPB), that the stronger the intention to engage in performing behavior, the more likely it is to conduct behavior. If someone has intention to do a behavior, that person will do the behavior; however, if someone does not have intention to do a behavior, that person tends not to do the behavior (Ajzen, 2005).

The Theory of Planned Behavior explains that intention is one's tendency or plan to do a behavior; in addition, it is a direct factor of behavior (Ajzen, 2005).

According to Azinar (2013), intention is one of the determinants of factors related to premarital sexual behavior in adolescents. Adolescents have a high curiosity, including the desire to become an adult. It causes an adolescent to have an intention to try and do everything that is conducted by adults, including matters relating to sexuality.

\section{The Effect of Perceived Behavioral \\ Control on Sexual Behavior in Female Adolescents}

The result of the study showed that strong perceived behavioral control had direct and positive effect on sexual behavior in female adolescents which was statistically significant $(b=2.42 ; 95 \% \mathrm{CI}=1.23$ to $3.61 ; \mathrm{p}$ $<0.001)$.

A study with similar result has also been carried out by Kumalaningrum et al., (2017), that there was a correlation between perceived behavioral control and healthy sexual behavior in female adolescents, Karanganyar.

\section{The Effect of Attitude on Sexual Behavior among Female Adoles- cents through Intention}

The result of this study showed that positive attitude had a direct and positive effect 
Journal of Health Promotion and Behavior (2019), 4(2): 126-136

https://doi.org/10.26911/thejhpb.2019.04.02.05

on positive intention in female adolescents $(b=1.45 ; 95 \% \mathrm{CI}=-0.04$ to $2.96 ; \mathrm{p}=0.057)$ and it was statistically marginally significant. This study showed that positive attitude would increase strong positive intention as well. Therefore, adolescents had strong intention not to do deviant sexual behavior.

According to Ajzen (2005) in the Theory of Planned Behavior, attitude (attitude toward behavior) is the amount of positive or negative feelings towards an object, person, institution, or activity. In addition, TPB also states that intention is affected by attitude. Attitudes which are affected by individual backgrounds include experience, knowledge, and media exposure.

Another study that supports the result of the analysis above is a study conducted by Ningsih et al., (2016) which states that adolescents had positive attitude; it means that adolescents do not intend to do the risky sexual behavior.

This study is in accordance with a study conducted by Kumalaningrum et al. (2017), that there is a correlation between sexual attitude and behavior in female adolescents in Karanganyar. It is also similar to a study conducted by Susanto et al., (2018), that there is a significant effect of attitude on premarital sexual behavior. Adolescents with weak attitude are more likely to do the risky sexual behavior (Kumalaningrum et al., 2017; Susanto et al., 2018).

In this study, the study subjects tended to have positive attitude, strong positive intention, and positive sexual behavior. This was likely because most of the study subjects have already gotten information about reproductive health both formally and informally. The information was formally obtained from school through biology/science subjects or physical/ health education. In addition, the information was informally obtained from parents, friends, books, and mostly obtained from the internet or social media.

\section{The Effect of Subjective Norm on Sexual Behavior among Female Adolescentsthrough Intention}

The result of this study indicated that positive subjective norm had a direct and positive effect on positive intention in female adolescents $(b=1.77 ; 95 \% \mathrm{CI}=0.21$ to 3.33 ; $\mathrm{p}=0.026$ ), and it was statistically significant.

This study showed that positive subjective norm would increase strong positive intention as well. Therefore, adolescents had strong intention not to do deviant sexual behavior. This is in accordance with the Theory of Planned Behavior (TPB), that one of the factors that can affect sexual behavior is intention. Intention is affected by 3 factors. one of these factors is subjecttive norm (Ajzen, 2005).

According to Ramdhani (2011), subjective norm is an individual perception about people expectation or other parties that is important to an individual's life in order to do or not to do certain behavior. In this case, other people of the important parties are parents, friends, and teachers. Based on the result of the study, the people expectation or other parties was significant enough to affect a female adolescent. Therefore, she has a strong intention not to do negative sexual behavior.

This study is in accordance with a study conducted by Kumalaningrum et al., (2017), that there is a correlation between subjective norm and healthy sexual behavior among female adolescents in Karanganyar.

This is in line with a study conducted by Sari et al., (2018), that premarital sexual behavior in adolescents may occurs due to poor interpersonal communication of 
parents and the influence of friends who have done sexual behavior.

If an adolescent has a good internal communication relationship with parents, they are able to lead her to the right direction if she has wrong knowledge about sexual behavior and bad relationship. It is because the parents know more about the knowledge and development of their children.

\section{The Effect of Perceived Behavioral Control on Sexual Behavior among Female Adolescents through intention}

The result of this study indicated that strong perceived behavioral control had a direct and positive effect on positive intention in female adolescents $(b=1.79 ; 95 \% \mathrm{CI}=$ 0.27 to $3.31 ; \mathrm{p}=0.021$ ), and it was statistically significant.

This study showed that strong perceived behavioral control would increase strong positive intention as well. Therefore, adolescents had strong intention not to do deviant sexual behavior.

This study is in line with a study conducted by Sumiatin et al., (2017), that positive perception of adolescents affects adolescents not to to do risky sexual behavior.

According to Tarmidi et al., (2018), there is a significant relationship between perceived behavioral control and sexual behavior through intention.

Perceived behavioral control is defined as self-efficacy. It is a belief that someone is easy to do or not easy to do certain behaviors, has the time and facileties to do the behavior, and estimates the ability of herself whether she has the ability or does not have the ability to carry out the behavior. This condition is defined as perceived behavioral control (Ajzen, 2005).

It is concluded that perceived behavioral control is a person's perception of the ability to control a behavior. It is the ability of a female adolescent to control herself to engage in positive or negative sexual behavior. Based on the result of this study, most of the female adolescents could control themselves not to engage in negative sexual behavior (Ajzen, 2005).

It probably occurred because most of the female adolescents had participated in the Youth Information and Counseling Center activities in their schools. Thereby, it increased their knowledge about reproductive health, especially about reproducetive health in adolescents. It was one of the strong reasons for these female adolescents to have strong perceived control. Therefore, it could increase the strong intention not to engage in negative sexual behavior.

\section{The Effect of Behavioral Belief on Intention to do Sexual Behavior through Attitude}

The result of this study indicated that positive behavioral beliefs had a direct and positive effect on attitude in female adolescents $(b=2.68 ; 95 \% \mathrm{CI}=1.76$ to $3.60 ; \mathrm{p}$ $<0.001$ ), and it was statistically significant.

This study showed that positive behavioral belief would increase positive attitude, so that the female adolescents had strong intention not to engage in deviant sexual behavior. This is in accordance with the Theory of Planned Behavior (TPB), that one of the factors that can affect sexual behavior is intention. Intention is affected by 3 factors: attitude, subjective norm, and perceived behavioral control. Meanwhile, attitude has several components that affect it. One of these components is behavioral belief. It is the belief that a person has on behavior and a belief that will encourage the formation of attitude (Ajzen, 2005).

According to Ohee et al., (2018), knowledge affects one's behavioral belief to determine attitude in behave. In other words, someone who has good knowledge 
Journal of Health Promotion and Behavior (2019), 4(2): 126-136

https://doi.org/10.26911/thejhpb.2019.04.02.05

will tend to have a good attitude. Therefore, she will behave well.

According to Putri et al., (2019), adolescents disagreed with free sex which could lead to early marriage or loss of virginity. It would make students tend to have a belief that negative sexual behavior was a bad behavior. It could harm herself, created poor self-image and family-image. The adolescents did not have negative attitude, so that they did not do that behavior.

\section{The Effect of Normative Belief on Intention to do Sexual Behavior through Subjective Norm}

The result of this study indicated that positive normative belief had a direct and positive effect on subjective norm in female adolescents $(b=1.36 ; 95 \% \mathrm{CI}=0.46$ to 2.26 ; $\mathrm{p}=0.003$ ), and it was statistically significant.

This study showed that positive normative belief would increase positive subjective norms as well, so that female adolescents had strong intention not to engage in deviant sexual behavior. This is in accordance with the Theory of Planned Behavior (TPB) (Ajzen, 2005), that one of the factors that can affect sexual behavior is intention. Intention is affected by 3 factors: attitude, subjective norm and perceived behavioral control. Meanwhile, subjective norm has several components that affect it. One of these components is normative belief. It is related to the opinions of important figures or other people who are influential to the individual or role model whether the subject must or must not do a certain behavior (Ajzen, 2005).

According to Lopez et al., (2015), sexual behavior in adolescents is affected by social networks both family and peers. Sexual behavior is partly affected by how acceptable the sexual behavior is and is believed by the adolescents. Adolescent perceptions of sexual behavior due to peer influence have been identified as important and initial predictors of sexual behavior.

This study is in line with a study conducted by Rahmawati et al., 2016), that social support affects a person in performing behavior. Social support from friends, support from family (parents) and support from a strong school environment can affect an adolescent in preventing premarital sexual behavior.

In this case, the positive opinion or beliefs of family, friends, teachers, and the closest people (normative belief) can affecta female adolescent to have positive belief about sexual behavior (subjective norm). Therefore, she has strong positive intention. In addition, it is possible for female adolescent to choose positive sexual behavior.

Based on a study conducted by Yadav et al., (2017), normative belief has a positive and significant effect on attitude. Attitude significantly affects intention to perform behavior.

\section{The Effect of Control Belief on Intention to do Sexual Behavior through Perceived Behavioral Control}

The result of this study indicated that strong control belief had a direct and positive effect on perceived behavioral control $(\mathrm{b}=1.44 ; 95 \% \mathrm{CI}=0.49$ to $2.39 ; \mathrm{p}=0.003$ ) which was statistically significant.

This study showed that strong behavioral belief would increase the strong perceived behavioral control as well. Therefore, female adolescents had strong intention not to engage in deviant sexual behavior. This study is in accordance with the Theory of Planned Behavior (TPB), that one of the factors that can affect sexual behavior is intention. Intention is affected by 3 factors: attitude, subjective norm, and perceived behavioral control. Meanwhile, perceived behavioral control has several com- 
ponents that affect it. One of these components is control belief. It is a belief regarding supporting and/or inhibiting factors to perform a behavior (Ajzen, 2005).

In this study, most of the female adolescents had strong behavioral belief. It was possible for female adolescents to have strong perceived behavioral control. Therefore, female adolescents had strong intention not to engage in negative sexual behavior. It probably occurred because there was the Youth Information and Counseling Center program in each school. As a result, it increased their knowledge about reproductive health. Besides, there was a religious subject in each school, thus developing their knowledge and faith.

A study by Yudhaprawira et al., (2017) reported that adolescents have been able to limit their sexual behavior due to strong faith. As a result, they do not engage in deviant sexual behavior. He also states that religion that someone has is not just knowledge, but it must be internalized in performing behavior, including relations with the opposite sex.

\section{AUTHOR CONTRIBUTION \\ Tri Ayu Setiowati, a main researcher who played a role in collecting and processing the dat. Eti Poncorini Pamungkasari exa- mined the conceptual framework and the study method. Hanung reviewed the script of the study.}

\section{SPONSORSHIP AND FUNDING}

This study used independent fund by the main author.

\section{CONFLICT OF INTEREST}

There is no conflict of interest.

\section{ACKNOWLEDGEMENT}

We give the best gratitude to the parties in the Senior High School in Bantul Regency and all parties who were involved in this study, so that it could run well.

\section{REFERENCE}

Ajzen I (2005). Attitudes, personality, and behavior ( $2^{\text {nd }}$ edition). New York: Open University Press.

Azinar M (2013). Perilaku seksual pranikah berisiko terhadap kehamilan tidak diinginkan. Jurnal kesehatan masyarakat (KEMAS). 8(2): 153-160.

BKKBN (2012). Profil hasil pendataan keluarga 2011. Jakarta: Direktorat pelaporan dan statistik.

Kementerian Kesehatan RI (2015) Situasi Kesehatan Reproduksi Remaja. Pusat Data dan Informasi Kementerian Kesehatan RI. Retrieved from http://www.depkes.go.id.

Kumalaningrum M, Pamungkasari EP, Nurhaeni IDA (2017). Multilevel analysis on the predictors of safe sexual behavior among girl adolescents in karanganyar, central java. Journal of Health Promotion and Behavior. 2(4): 323-331. Retrieved from https://doi.org/10.26911/thejhpb.2017.02.04.04.

Lopez JR, Mukaire PE, Mataya RH (2015). Characteristics of youth sexual and reproductive health and risky behaviors in two rural provinces of Cambodia. Reproductive health, 1-12. Retrieved from https://doi.org/10.1186/s12978-015-0052-5

Ningsih WT, Purwanto $H$, Sumiatin T (2016). Pengaruh sikap remaja tentang perilaku seks dan niat remaja dalam melakukan perilaku seks beresiko. The Indonesian Journal of Health Science (TIJHS). 7(1): 48-53.

Ohee C, Purnomo W (2018). Pengaruh status hubungan berpacaran terhadap 
Journal of Health Promotion and Behavior (2019), 4(2): 126-136

https://doi.org/10.26911/thejhpb.2019.04.02.05

perilaku pacaran berisiko pada mahasiswa perantau asal papua di kota surabaya. The Indonesian Journal of Public Health (IJPH). 13(2): 268280. Retrieved from https://doi.org/ 10.20473/ijph.vl13il.2018.268-280

Putri DAJ (2019). Studi deskriptif tentang pola asuh otoritatif, kontrol diri dan sikap remaja terhadap perilaku seks bebas. Biblio Couns : Jurnal Kajian Konseling dan Pendidikan. 2(2): 7888. Doi: https://doi.org/10.30596/bibliocouns.v2i2.3230.

Rahmawati CD, Devy SR (2016). Social support which encourage premarital sex behavior in senior high school $\mathrm{x}$ adolescent in surabaya. Jurnal Promkes. 4(2): 129-139.

Ramdhani N (2011). Penyusunan alat pengukur berbasis theory of planned behavior. Buletin Psikologi Fakultas Peikologi Universitas Gadjah Mada. 19(2): 55-69.

Sari DN, Darmana A, Muhammad I (2018). The effect of predisposition factors, allowers, and supporters to sexual behavior of adolescent at asuhan daya senior high school medan. Jurnal Kesehatan Global. 1(2): 53-60.

Sumiatin T, Purwanto $H$, Ningsih WT (2017). The influence of teenagers; perception about sex behavior towards their interest in doing risky sex behavior. 8: 96-101. Retrieved from http://ejournal.umm.ac.id/index.php /keperawatan/issue/view.
Suryoputro A, Ford NJ, Shaluhiyah Z (2006). Faktor-faktor yang mempengaruhi perilaku seksual dan layanan kesehatan seksual dan reproduksi. Makara Kesehatan. 10(1): 2940.

Susanto BNA, Nurhaeni IDA, Pamungkasari EP (2018). Do schools affect unsafe sexual behaviors among high school students in boyolali, central java? A multilevel analysis approach. Journal of Health Promotion and Behavior. 4(2): 230-239. Retrieved from https://doi.org/10.26911/thejhpb.2018.03.04.02.

Tarmidi M, Demartoto A, Pamungkasari EP (2018) Faktors associated with premarital sexual behavior among adolescents in Bima, West Nusa Tenggara: Theory of planned behavior. Journal of Health Promotion and Behavior. 3(1): 78-85. Retrieved from https://doi.org/10.26911/thejhpb.201 8.03.01.08.

Yadav R, Pathak GS (2017). Determinants of consumers'green purchase behavior in a developing nation: applying and extending the theory of planned behavior. Ecological economics. 134, 114-122. Retrieved from https://doi.org/10.1016/j.ecolecon.2016.12.019

Yudhaprawira MR, Uyun Z (2017). Kematangan beragama remaja akhir sebagai pelaku seksual pranikah. Jurnal Indigenous. 2(1): 49-59. 